\author{
Łukasz Chyla* \\ ORCID: 0000-0001-7353-8125
}

Jagiellonian University in Kraków

https://doi.org/10.19195/1733-5779.34.2

\title{
Exempt offerings in the EU and the US: A comparative perspective ${ }^{\star *}$
}

JEL Classification: G14, G15, K33

Keywords: EU prospectus law, US prospectus law, prospectus exemption, EU Regulation 2017/1129, private primary markets

Slowa kluczowe: europejskie prawo prospektowe, amerykańskie prawo prospektowe, wyłączenia prospektowe, rozporządzenie UE 2017/1129, prywatne rynki pierwotne

Abstract: The prospectus - exempted offering framework plays a crucial role in the process of creating more issuers - friendly capital markets by minimizing the "barriers to entry" (such as burdensome prospectus obligations and ongoing disclosure thereafter). Thanks to certain prospectus exemptions, SMEs have better opportunities to access critical funds in order to grow and scale. In recognition of the above, prospectus law in the European Union and the United States has lately been subject to dynamic reforms, aimed at expanding the exempt offerings frameworks. In the EU, a landmark reform, followed by multiple changes on a national level, has been introduced by the Prospectus Regulation (EU) 2017/1129. In the US, for many years now, we have been observing major exempt offerings reforms, such as the "JOBS Act", the "FAST Act" and the "Economic Growth Act", followed by the SEC rules. The main objective of this article is to analyze and evaluate, from a comparative perspective, the EU and the US legal frameworks for offers exempted from prospectus obligations - especially in light of the latest reforms. The article is based mostly on scrutinizing sources of law, academic literature, reports and data published by market authorities.

${ }^{*}$ Scientific Tutor (Opiekun naukowy) — prof. dr hab. Andrzej Szumański

** The article was written as part of the Polish National Center for Science scientific grant "Preludium" (No. 2018/29/N/HS5/02977).

Studenckie Prace Prawnicze, Administratywistyczne i Ekonomiczne 34

Studenckie Prace Prawnicze, Administratywistyczne i Ekonomiczne 34, 2020

(C) for this edition by CNS 


\title{
Zwolnienia od obowiązku sporządzania prospektu emisyjnego w UE i USA - perspektywa porównawcza
}

\begin{abstract}
Abstrakt: Wyłączenia od obowiązku sporządzenia prospektu emisyjnego odgrywają kluczową rolę w procesie kreowania bardziej przyjaznych dla emitentów rynków kapitałowych poprzez minimalizowanie „barier wejścia”. Dzięki tym wyłączeniom MŚP mają lepsze możliwości dostępu do kapitału w celu dalszego proporcjonalnego rozwoju. W związku z tym prawo prospektowe w Unii Europejskiej i Stanach Zjednoczonych zostało ostatnio poddane dynamicznym reformom, w ramach których między innymi rozszerzono wyłączenia prospektowe. W UE przełomowa reforma, po której nastąpiły liczne zmiany na poziomie krajowym, została wprowadzona rozporządzeniem prospektowym (UE) 2017/1129. Z kolei w Stanach Zjednoczonych od wielu lat obserwujemy poważne reformy ułatwiające przeprowadzenie emisji papierów wartościowych, takie jak „JOBS Act”, „FAST Act” i „Economic Growth Act”, a także liczne regulacje SEC. Głównym celem artykułu jest analiza i ocena, z perspektywy porównawczej, ram prawnych UE i USA dla ofert zwolnionych z obowiązków prospektowych — zwłaszcza w świetle ostatnich reform. Tekst opiera się głównie na analizie źródeł prawa, literatury naukowej, raportów i danych publikowanych przez autorytety rynkowe.
\end{abstract}

\section{Introduction}

One of the main challenges faced worldwide by prospectus regulations, is to create a more issuers-friendly environment by minimizing the "barriers to entry", such as compliance costs. In doing so, a model prospectus law should carefully strike a balance so it can best address the sometimes opposing (albeit equally justified) needs of various actors - not only the issuers' need for cheap funding without excessive burdens, but also the investors' need for appropriate disclosure and market oversight, and finally - the general need to increase the competitiveness and attractiveness of the capital markets vis-a-vis the banking system.

The exempt offering framework plays a crucial role in this process. It allows certain small capital raisings to skip burdensome prospectus obligations and ongoing disclosure thereafter. Thanks to certain prospectus exemptions, multiple small companies ${ }^{1}$ have the opportunity to access critical funds in order to grow and scale. ${ }^{2}$ Exempt offerings can also satisfy the capital needs of some SMEs that are unlikely to become public companies due to their size or business nature. ${ }^{3}$ In other words, the dynamics of capital markets depends highly on a robust pipeline of new companies - supported by the exempt offering framework - that can eventually enter the public markets "in full grace".

In pursuit of these goals, prospectus law in the European Union and the United States has lately been subject to dynamic reforms. In the EU, a landmark prospec-

${ }^{1}$ From early-stage start-ups seeking seed capital to companies that are on a clear path to going public.

2 See: Office of the Advocate for Small Business Capital Formation Annual Report for Fiscal Year 2019, p. 11, https://www.sec.gov/files/2019_OASB_Annual\%20Report.pdf(accessed: 1.07.2020).

${ }^{3}$ Ibidem. 
tus law reform, followed by multiple changes on a national level, has lately been introduced by the Prospectus Regulation (EU) 2017/11294 and other secondary laws, ${ }^{5}$ with the intention of enhancing the market's efficiency and attractiveness against its US counterpart. In addition, further amendments are being discussed and proposed by experts and political leaders. In the US, for many years now, we have been observing major exempt offerings reforms, such as the "JOBS Act" (2012), ${ }^{6}$ the "FAST Act" (2015) ${ }^{7}$ and the "Economic Growth Act" (2018), ${ }^{8}$ followed by multiple rules established by the Securities and Exchange Commission ("SEC"). In addition, even more laws have lately been proposed, including the "JOBS Act 3.0" and "Facilitating Capital Formation" SEC Proposal (2020).9

Changes on both sides of the Atlantic represent a clear, ongoing trend of liberalization toward prospectus obligations to increase the competitiveness and attractiveness of local capital markets vis a vis other jurisdiction (this process is often called "regulator shopping").

Since the European solutions on exempt offerings differ significantly from the American ones, these divergences may hold the key to understanding the lower efficacy and competitiveness of the European markets. Hence, to draw from the US experience, it is particularly important for European legal scholars to better understand the rationale behind US changes. Meanwhile, for their American peers, it might be equally valuable to grasp some insights into the EU Prospectus Regulation perspective (especially in the face of their own impending reforms).Therefore, the aim of this article is to comparatively analyze and evaluate the exempt offering frameworks in the EU and the US in light of the latest changes.

\section{The exempt offerings in the EU}

Prospectus law in the European Union is governed by the Prospectus Regulation (EU) 2017/1129, which provides for a single regime throughout the whole Union and European Economic Area (EEA). It lays down the requirements for the drawing up, approval, and distribution of a prospectus to be published when securities are offered to the public or admitted to trading on a regulated market within a Member State. This new prospectus law, which replaced the previous Prospectus

4 Regulation (EU) 2017/1129 of the European Parliament and of the Council of 14 June 2017 on the prospectus to be published when securities are offered to the public or admitted to trading on a regulated market, and repealing Directive 2003/71/EC.

5 Such as the Commission Delegated Regulations 2019/980 and 2019/979, ESMA Guidelines, etc.

6 Pub. L. No. 112-106, 126 Stat. 306 (2012).

7 Pub. L. No. 114-94, 129 Stat. 1312 (2015).

8 Pub. L. No. 115-174, 132 Stat. 1296 (2018).

9 Facilitating Capital Formation and Expanding Investment Opportunities by Improving Access to Capital in Private Markets, SEC Release Nos. 33-10763; 34-88321; File No. S7-05-20. 
Directive 2003/71/EC, ${ }^{10}$ entered into force on 20 July 2017 and applied fully from 21 July 2019. ${ }^{11}$ Contrary to the Directive, the Prospectus Regulation is directly binding and fully applicable in all EU Member States without any further implementation. The new law is a realization of the European Capital Markets Union Plan ("CMU"), ${ }^{12}$ the flagship EU project which reflects a long-term ambition to expand and diversify sources of funding alternative to bank lending, and to help EU companies to better finance their expansion in order to create jobs and growth. ${ }^{13}$ One of the major aims of the Regulation is to enhance the internal EU market for capital. ${ }^{14}$ In order to achieve this goal, it introduced a number of sweeping changes, including, in particular, a significant increase in the exemption thresholds from the prospectus obligation (the "lower threshold" from EUR 100,000 to 1 million EUR and the "upper threshold" from EUR 5 million to 8 million EUR).

In general, under the Prospectus Regulation (Article 3(1)) securities shall only be offered to the public in the EU after the prior publication of an EU - compliant prospectus (unless there is an exemption available). Before a prospectus can be published, it has to be submitted and approved by the relevant national competent authority (Article 20(1)). Subsequently, the competent national authority notifies the issuer and the Exchange and Securities Market Authority ("ESMA") of the approval. Once approved, the prospectus has to be made public by the issuer at the latest by the beginning of the offer (Article 21). Importantly, under the Pro-

10 Directive 2003/71/EC of the European Parliament and of the Council of 4 November 2003 on the prospectus to be published when securities are offered to the public or admitted to trading and amending Directive 2001/34/EC.

11 The Prospectus Regulation (2017/1129) was published in the Official Journal on 30 June 2017 and came into force on 20 July 2017. However, the vast majority of its provisions have effect from 21 July 2019. Articles 1(5) (a)(b)(c) and 1(5) subparagraph 2 are subject to an earlier application date than the majority of the provisions of the Prospectus Regulation and became applicable on 2 July 2017 (prospectus exemption for the admission to trading of additional securities of the same class as, and amounting to $20 \%$ of the number of, those already admitted to the same regulated market). Articles 1(3) and 3(2) are subject to an earlier application date than the majority of the provisions of the Prospectus Regulation and became applicable on 21 July 2018 (exemption thresholds below which the prospectus is not required).

12 Capital Markets Union - Communication of the Commission of 30 September 2015, entitled Action Plan on Building a Capital Markets Union; The European Commission Staff Working Document Impact Assessment accompanying the document Proposal for a Regulation of the European Parliament and of the Council on the prospectus to be published when securities are offered to the public or admitted to trading, Brussels, 30.11.2015, Annex 3, p. 6. The regulation is also part of the European Commission's (hereinafter referred to as EC) more general commitment to simplifying EU laws and making them more efficient (REFIT). See: The European Commission's regulatory fitness and performance (REFIT) programme. Available: https://ec.europa.eu/info/law/ law-making-process/evaluating-and-improving-existing-laws/refit-making-eu-law-simpler-andless-costly_en (accessed: 20.06.2019).

13 Recital (1) of the PR.

14 Recital (7) of the PR. 
spectus Regulation, once a prospectus has been approved in one $E U$ country, it is valid throughout the whole $E U$ (the passporting procedure). ${ }^{15}$

In order to promote capital formation by SMEs, the Prospectus Regulation sets forth a number of exemptions from prospectus obligations, of which the two most relevant are described below. Unlike in the US, the EU exempted offers are not subject to any restrictions with respect to advertisement and solicitation. However, making use of exemptions comes at a price. Such offers cannot be subject to the notification procedure, ${ }^{16}$ and consequently, cannot benefit from the passporting regime under the Regulation. ${ }^{17}$ Thus, despite the fact that the exemption framework on the EU level is relatively straightforward, it can still be subject to various disclosure requirements imposed within the states' discretion and autonomy, which creates confusion- especially for smaller issuers with no adequate research resources.

\section{Offers exempted due to the limited value}

Pursuant to Article 1(3) of the Prospectus Regulation, the obligation to publish a prospectus does not apply to an offer of securities to the public with a total consideration in the EU of less than EUR 1 million over 12 months. According to Article 1(3) subparagraph 2, Member States shall not extend the obligation to draw up a prospectus below EUR 1 million ("lower threshold"). However, in those cases, Member States may require other disclosure requirements at the national level to the extent that such requirements do not constitute a disproportionate or unnecessary burden.

Additionally, pursuant to Article 3(2) of the PR, Member States may decide to exempt offers from the obligation to publish a prospectus provided that the total consideration of each such offer in the Union does not exceed EUR 8 million over 12 months. Also below that threshold, Member States are free to require other disclosure requirements at the national level as long as such requirements do not constitute a disproportionate or unnecessary burden in relation to such exempted offers of securities. ${ }^{18}$ As mentioned before, such offers cannot benefit from the passporting regime under the Regulation. ${ }^{19}$ Moreover, the exemption thresholds are not applicable to the admission to trading on regulated markets. These limitations are often heavily criticized by experts. ${ }^{20}$

Upholding the MS discretion in setting out a threshold between EUR 1 and 8 million (as well as their discretion to impose additional national disclosure rules

15 See: Articles 24, 25 of the Prospectus Regulation 2017/1129.

16 Article 25 of the Prospectus Regulation 2017/1129.

17 Recital (13) of the Prospectus Regulation 2017/1129.

18 Recital (12) of the Prospectus Regulation 2017/1129.

19 Recital (13) of the PR.

20 A. Casale, M. Bianchi, P. Spatola, "The New Prospectus Regulation: A Missed Opportunity?”, Oxford Business Law Blog, 2017, https://www.law.ox.ac.uk/business-law-blog/blog/2017/03/ new-prospectus-regulation-missed-opportunity (accessed: 1.07.2020). 
below this threshold), according to their perception of the appropriate level of domestic investor protection, was motivated by the varying sizes of financial markets across the EU. ${ }^{21}$ Member States are required to notify the European Commission and ESMA of whether and how they decide to use the exemption in Article 3(2), as well as any subsequent changes to that policy.

The increase in the upper exemption threshold from EUR 5 million to EUR 8 million was almost immediately reflected in the subsequent legislative tendency of the Member States (Table 1). The numbers speak for themselves - since 2016, at least 17 states have used the opportunity to raise their thresholds ${ }^{22}$ (of which 14 raised the threshold to the maximum EUR 8 million), and another 3 are now in the process of implementing higher thresholds. ${ }^{23}$

Table 1. Threshold above which members of the EEA require an EU prospectus to be drawn up $(2019)^{*}$

\begin{tabular}{|c|c|c|c|c|c|}
\hline $\begin{array}{c}\text { Threshold } \\
\text { (EUR) }\end{array}$ & $1,000,000$ & $2,500,000$ & $3,000,000$ & $5,000,000$ & $8,000,000$ \\
\hline $\begin{array}{c}\text { Member } \\
\text { States }\end{array}$ & $\begin{array}{l}\text { Bulgaria, } \\
\text { Czechia, } \\
\text { Hungary, } \\
\text { Slovakia }\end{array}$ & $\begin{array}{l}\text { Poland, } \\
\text { Sweden }\end{array}$ & Slovenia & $\begin{array}{c}\text { Austria, } \\
\text { Croatia, } \\
\text { Cyprus, } \\
\text { Greece, } \\
\text { Iceland, } \\
\text { Malta, } \\
\text { The } \\
\text { Netherlands, } \\
\text { Portugal, } \\
\text { Romania, } \\
\text { Spain }\end{array}$ & $\begin{array}{c}\text { Belgium, } \\
\text { Denmark, } \\
\text { Estonia, } \\
\text { Finland, } \\
\text { France, } \\
\text { Germany, } \\
\text { Ireland, } \\
\text { Italy, } \\
\text { Latvia, } \\
\text { Liechtenstein, } \\
\text { Lithuania, } \\
\text { Luxembourg, } \\
\text { Norway, } \\
\text { United } \\
\text { Kingdom }\end{array}$ \\
\hline
\end{tabular}

* Expressed as the total consideration of the offer in the EU over 12 months. The countries that raised the exemption thresholds since 2016 are mentioned in bold font.

Source: own work.

In consequence, as of 2020, in Belgium, Denmark, Estonia, Finland, France, Germany, Ireland, Italy, Latvia, Liechtenstein, Lithuania, Luxembourg, Norway, and the United Kingdom, the exemption threshold is EUR 8 million. In Austria, Croatia, Cyprus, Greece, Iceland, Malta, the Netherlands, Portugal, Romania,

21 Recital (13) of the PR.

22 Ł. Chyla, "Is a 2.5 million EUR prospectus exemption threshold enough?", Przeglad Prawno-Ekonomiczny 47, 2019.

${ }^{23}$ Bulgaria, Greece, Iceland. 
and Spain the threshold is EUR 5 million. In Romania, there is a EUR 5 million threshold for offers made exclusively in Member States other than Romania, ${ }^{24}$ and a EUR 1 million threshold for offers made within Romania. ${ }^{25}$ In Slovenia, the threshold is EUR 3 million, while in Poland and Sweden - EUR 2.5 million. The lowest exemption thresholds of EUR 1 million (the admissible minimum) are in Bulgaria, Czechia, Hungary, Latvia, and Slovakia.

As a consequence, the EU exemption framework seems to be visibly inconsistent. As shown above, full discretion and flexibility in setting the upper exemption threshold result in a high diversity among Member States. The thresholds differ significantly, ranging randomly from EUR 1 to 8 million, often regardless of the economic development of the particular markets. In consequence, issuers from states with a lower threshold have a natural incentive to conduct an offering under a more favorable regime. This, in turn, creates severe cross-border concerns of forum shopping. ${ }^{26}$ Moreover, the disclosure requirements faced by the issuers of exempted offerings are extremely diverse across the EU, which might cause even further fragmentation and uncertainty in the markets. Firstly, there are at least 10 states that do not require any particular disclosure for such offers neither to the public nor to the competent national authorities. ${ }^{27}$ Secondly, there is a large group of countries that impose very little information obligations - either in the form of short information notes, short documents, or even press releases ${ }^{28}$ the majority of which do not require any prior approval by the competent authority. ${ }^{29}$ In some countries, bare notification of the use of the exemption suffice. ${ }^{30}$ Thirdly, some countries have more strict disclosure requirements, which require submission of lengthy information documents or special national prospectuses, the majority of which have to be approved by competent authority prior to publication. ${ }^{31}$

As a result, in numerous states, issuers offering securities to the public with a total consideration of EUR 8 million will face significantly fewer obstacles (or even no disclosure requirements at all) than conducting a public offering with

24 See Article 5, paragraph 2, Romanian Regulation no. 5/2018 on issuers of financial instruments and market operations.

25 See Article 5, paragraph 1(h), Romanian Law no. 24/2017 on issuers of financial instruments and market operations.

${ }^{26}$ E. Härkönen, "Crowdfunding and the Small Offering Exemption in European and US Prospectus Regulation: Striking a Balance Between Investor Protection and Access to Capital?", European Company and Financial Law Review 14, 2017, no. 1, p. 130.

27 Bulgaria, Cyprus, Czechia, Denmark, Malta, Portugal, Romania, Slovakia, Spain, and Sweden.

28 Such as Belgium, Finland, France, Lithuania, Netherlands, Latvia, United Kingdom.

29 Except for Germany, where the short (up to 3 A4 pages) information document (WIB) needs to be approved by BaFin.

30 Croatia, Slovenia.

31 Estonia, Norway, Greece, Iceland, Poland, Hungary. 
a total consideration of EUR 1 million in other states. ${ }^{32}$ This concerns not only more developed economies, such as Belgium, France, UK, Italy, or Germany, but also countries with modest depth and development levels of capital markets opportunities - such as Lithuania or Latvia.

Finally, the lack of a passporting procedure in case of exempted offerings might deepen the financial fragmentation of the EU markets in the long run. Issuers in member states with a higher exemption threshold or with no particular disclosure requirements can only offer their securities to domestic investors. In practice, with the international nature of crowd-funding and easy Internet access available for potential investors in other states, SMEs using a crowd-funding platform need to be wary of potential liability risk cross-border investors. ${ }^{33}$

All this lack of coherence and harmonization might have a negative effect on the EU capital markets, hindering the achievements of the PR toward the CMU.

\section{Offers to qualified and a limited number of non-qualified investors}

Pursuant to the Prospectus Regulation, ${ }^{34}$ which fully retained the Prospectus Directive solutions in this matter, the obligation to publish a prospectus shall not apply to offers of securities addressed solely to qualified investors or to fewer than 150 non-qualified investors (often referred to as a "private placement" exemption). Since under the Regulation, various exemptions are not exclusive and can be used jointly with other ones, the issuance of shares to a limited number of 149 non-qualified investors in each of a number of Member States can be further broadened by exemption covering issues of up to EUR 8 million or exemption covering issues to an unlimited number of qualified investors.

The original objective of the exemption was to serve as a kind of de minimis clause allowing issuers in a private placement to include a restricted circle of non-qualified investors in their offers. ${ }^{35}$ However, as a consequence of the enlargement of the EU, issuers can now offer to sell its securities to more than 4,000 non-qualified investors, without triggering any prospectus requirements whatsoever. ${ }^{36}$ This might be problematic at least as it runs counter to the objective of investor protection. Surprisingly, the European Commission even considered raising this limit to 300 or even 500 persons in order to further benefit the development of crowd-funding across the EU. ${ }^{37}$ However, this idea was abandoned since the vast majority of crowd-funding offers, despite reaching more than 150 non-qualified

32 Such as Poland or Hungary.

33 E. Härkönen, op. cit., p. 128.

34 Article 1(4) of the Prospectus Regulation 2017/1129.

35 The European Commission Staff Working Document..., p. 21.

36 E. Härkönen, op. cit., p. 128; The European Commission Staff Working Document..., p. 19.

37 It was reported that in the UK, where crowd-funding is most developed, the average number of investors ranges from 50 to 400 persons. See: The European Commission Staff Working Document..., p. 20. 
investors can still enjoy the $8 \mathrm{mln}$ EU exemption threshold. ${ }^{38}$ Nevertheless, the biggest threat to the smooth development of equity crowd-funding across the EU lies in the Member States' discretion to extend the prospectus disclosure requirements below that threshold. As shown above, the diversity of domestic regulations is a substantial entry barrier for the issuers.

\section{Exempt offerings in the US}

Securities law in the United States involves dual regulation and is facilitated by both federal laws and the laws of the particular state in which securities are offered (the so-called blue state laws ${ }^{39}$ ). The focus of this analysis is on federal laws only, since most federal exempt offerings create securities classified as covered securities, which preempt state registration (and other state disclosure requirements) and thus are subject only to federal regulations. ${ }^{40}$

The Securities Act of $1933^{41}$ requires that every offer ${ }^{42}$ and sale of securities be registered ${ }^{43}$ with the Securities and Exchange Commission (the "SEC"), unless an

38 According to ESMA's report Investment-based crowd-funding: insights from regulators in the EU of May 2015, the average amount raised via the UK crowd-funding platforms between 2011 and the first quarter of 2014 was the equivalent of 270,000 EUR.

39 The term originated after one of the state lawmakers declared that "if securities legislation was not passed, financial pirates would sell citizens everything in his state but the blue sky", referring to a once widespread problem of financial piracy in the United States. "These financial pirates were engaged in the widespread sale of 'pieces of paper' representing ownership in various corporate enterprises, many of which were valueless or nonexistent". See: M.G. Warren, "Reflections on Dual Regulation of Securities: A Case Against Preemption (May 1, 1984)", Boston College Law Review 25, 1984, no. 3, p. 1.

40 Traditionally, blue sky laws were not preempted by the Securities Act of 1933 and the Securities Exchange Act of 1934. Although many state laws are based on the Uniform Securities Act (USA) of 1956, designed as a template, most of them adopted variations that added to their complexity and diversity across states — not to mention the variation in judicial interpretations. In recent years, there have been continuous efforts to harmonize the securities legal framework in order to reduce unnecessary obstacles to capital formation. To achieve uniformity and reduce the burden on issuers, the National Securities Markets Improvement Act (NSMIA) of 1996 has been passed. It classifies certain types of securities as covered securities, which are exempt from state registration and requirements and thus subject only to federal law.

41 See: Section 5 of the Securities Act of 1933, 15 U.S.C. $\$ 77$ a et seq.

42 See: 15 U.S.C. 77b(a)(3) (an offer includes every attempt to dispose of a security or interest in a security, for value; or any solicitation of an offer to buy a security or interest in a security).

43 The Securities Act requires a company to file a registration statement with the SEC before it may offer its securities for sale. Issuers are not supposed to sell securities covered by the registration statement until the SEC staff declares the registration statement as "effective". The registration statement contains two essential parts. Part I is the prospectus, in which an issuer must clearly describe important information about its business operations, financial condition, results of operations, risk factors, and management. The prospectus must also include audited financial statements. The prospectus has to be delivered to every offeree (prospective investors). Part II contains 
exemption from registration is available. ${ }^{44} \mathrm{An}$ issuer who has filed a registration statement with the SEC becomes subject to regular disclosure obligations under the Securities Exchange Act of 1934. However, taking into account that registration is not always the most effective solution, the Securities Act sets forth a number of exemptions from its registration requirement ${ }^{45}$ as well as some additional exemptions the SEC is authorized to adopt. ${ }^{46}$

Without a doubt, the US exempt offering framework is substantially more complex and diversified than the EU one. It has evolved and significantly expanded over time through SEC rules and major legislative changes, such as the Jumpstart Our Business Startups Act of 2012 ("JOBS Act"), ${ }^{47}$ Fixing America's Surface Transportation Act of 2015 (the "FAST Act") 48 and the Economic Growth, Regulatory Relief, and Consumer Protection Act of 2018 (the "Economic Growth Act"). ${ }^{49}$ In recent Over the past years, there has been a noticeable trend of increasing liberalization of the US prospectus law by raising the prospectus exemption thresholds and facilitating the use of these thresholds for smaller companies. At the same time, exemptions are still carefully balanced so as to where non-accredited investors are permitted to participate in the offering they usually include more investor protection..$^{50}$ It is worth noting, that the exempt offerings market in the US is highly successful. The SEC estimates that in 2019, exempt offerings accounted for USD 2.7 trillion (69.2 percent) of new capital compared to USD 1.2 trillion (30.8 percent) raised through registered offerings. ${ }^{51}$ Despite the fact that there are many types of exemptions, the focus of this analysis is put only on the following federal regulations: Regulation D, Regulation A and Regulation Crowd-funding. ${ }^{52}$

additional information and exhibits which must be filed with the SEC but there is no obligation to deliver them to offerees (prospective investors).

44 SEC Proposed Rule: Facilitating Capital Formation and Expanding Investment Opportunities by Improving Access to Capital in Private Markets (03/31/2020), p. 6.

45 Section 3 of the Securities Act identifies types of securities that are exempt from the registration requirements, whereas section 4 of the Securities Act identify transactions that are exempt from the registration requirements.

${ }^{46}$ For instance, section 28 of the Securities Act, authorizes the Commission to exempt other persons, securities, or transactions to the extent "necessary or appropriate in the public interest and consistent with the protection of investors. Section 28 was added by the National Securities Markets Improvement Act of 1996 ("NSMIA"), See: Pub. L. No. 104-290, 110 Stat. 3416 (Oct. 11, 1996).

47 Pub. L. No. 112-106, 126 Stat. 306 (2012).

48 Pub. L. No. 114-94, 129 Stat. 1312 (2015).

49 Pub. L. No. 115-174, 132 Stat. 1296 (2018).

50 SEC Proposed Rule: Facilitating Capital Formation..., p. 13.

51 Based on analyses by staff in the Commission's Division of Economic Risk and Analysis ("DERA") of data collected from SEC filings. See: Concept Release on Harmonization of Securities Offering Exemptions, Release No. 33-10649 (June 18, 2019) [84 FR 30460 (June 26, 2019)], at Section II

52 For the reasons specified below, the exemptions excluded from the analysis are: Section 4(a) (2) offerings, Rule 144A offerings, Regulation S offerings, Rule 147 and Rule 147A Intrastate 


\section{Regulation D}

SEC Regulation $\mathrm{D}^{53}$ establishes the most significant exempt offerings regime, by setting forth three separate exemptions from the registration requirements of the Securities Act. The SEC estimates, that in 2019, issuers in the Regulation D market raised approximately USD 1.56 trillion of which the vast majority (USD 1.5 trillion) was raised under Rule 506(b). ${ }^{54}$ The offerings under Rule 506(c) raised approximately USD 66 billion, while offerings under Rule 504 raised only around USD 228 million. ${ }^{55}$

The first one, and by far the most popular, Rule 506(b) of Regulation D (referred to as "private placement"), is considered a "safe harbor" under Section 4(a)(2) of the Securities Act. Section 4(a)(2) only vaguely exempts from registration transactions by an issuer not involving any public offering. ${ }^{56}$ According to Rule 506(b) exemption, an issuer may offer and sell an unlimited amount of securities, provided that offers are made without the use of general solicitation or general advertising ${ }^{57}$ and sales are made only to accredited investors and maximally 35 non-accredited, yet sophisticated investors. ${ }^{58}$

offerings. Section 4(a)(2) of the Securities Act offerings are barely used since its criteria are vague and there is a convenient safe harbor available under Rule 506(b) of SEC Regulation D. Rule 144A is a safe harbor exemption from the registration requirements of Section 5. It applies to resales of securities to qualified institutional buyers only and can be used only by persons other than the issuer of the securities. Regulation $\mathrm{S}$ offerings allow for issuers to raise capital only outside the U.S. Rule 147 and Rule 147A provide for the intrastate offerings. Because this type of offering includes no more than one state, it is exempted from federal law and jurisdiction of the SEC. It does, however, fall under the jurisdiction of particular state authorities. Rule 147 is a "safe harbor" under Section 3(a)(11) of the Securities Act and provides objective standards that an issuer can rely on to meet the requirements of that exemption. Rule 147A is an intrastate offering exemption adopted by the Commission in 2016. According to the SEC, it seeks to accommodate modern business practices and communications technology and allows to raise capital locally, for instance by intrastate crowd-funding offerings.

5317 C.F.R. $\$ 230.501$ et seq.

54 SEC Proposed Rule: Facilitating Capital Formation..., p. 15.

55 Ibidem, p. 16.

56 The so-called "private placement" exemption under Section 4(a)(2) of the Securities Act requires, that the purchasers of the securities: a) either have enough knowledge and experience in finance and business matters to be "sophisticated investors" (able to evaluate the risks and merits of the investment), or be able to bear the investment's economic risk, b) have access to the type of information normally provided in a prospectus for a registered securities offering and c) agree not to resell or distribute the securities to the public. If the issuer offers securities to even one person who does not meet these conditions, the entire offering may be in violation of the Securities Act. Hence, the more purchasers involved in the offering, the higher the risk of not complying with Section 4(a)(2) requirements. To mitigate this risk, Rule 506(b) provides objective standards that a company can rely on to meet the requirements of Section 4(a)(2) exemption.

57 Rule 502 (c).

58 Sophisticated investors shall meet an investment sophistication standard pursuant to Rule 506(b)(2)(ii) (stating that each purchaser who is not an accredited investor either alone or with 
The second most popular exemption, Rule 506(c) of Regulation D, sets forth an exemption without any limitation on offering amount pursuant to which offers may be made with the use of general solicitation or general advertising. However, the eligible purchasers in the Rule 506(c) offering are only limited to accredited investors and the issuer is obliged to take reasonable steps to verify their accredited investor status (because of that, this exemption is often referred to as "accredited investor crowd-funding").

Both rule 506(b) and 506(c) provide a federal preemption from state registration and qualification. ${ }^{59}$ Purchasers in offerings under both rules receive "restricted securities", with limitations on resale. ${ }^{60}$

A third exemption, and the least popular one, Rule 504 of Regulation D, exempts from registration the offer and sale of up to USD 5 million of securities in a 12-month period. It was adopted by the SEC, due to its authority under Section 3(b)(1) of the Securities Act. ${ }^{61}$ Unlike other exempt offerings, rule 504 requires a company to comply with securities laws of states in which securities are offered or sold. In general, like under Rule 506(b) offers are to be made without the use of general solicitation or general advertising, and similarly to Rule 506(b) and 506(c) purchasers receive only "restricted securities". ${ }^{62}$ Rule 504 is the only Regulation D exemption in which non-accredited investors can freely participate. In order to enhance the attractiveness of the Rule 504, the SEC has recently proposed to raise the exemption threshold to USD 10 million.

All Regulation D offerings are subject to "bad actor" disqualification provisions, which provides extra protection for investors against criminal and fraudulent activity by eliminating certain issuers from exempt offerings. ${ }^{63}$

On the surface, Regulation D seems to be quite similar to the EU exemption framework. For instance, Rules 506(b) and 506(c) can be compared to Prospectus

a purchaser representative has such knowledge and experience in financial and business matters that such purchaser is capable of evaluating the merits and risks of the prospective investment, or the issuer reasonably believes immediately prior to making any sale that such purchaser comes within that description).

${ }^{59}$ However, the states still retain the authority to require notice filings and collect state fees. See: Section 18 of the Securities Act.

${ }^{60}$ According to rule $502 \mathrm{~d}$, except as provided in $\$ 230.504(\mathrm{~b})(1)$, securities acquired in a transaction under Regulation D shall have the status of securities acquired in a transaction under section 4(a)(2) of the Act and cannot be resold without registration under the Act or an exemption therefrom.

${ }^{61}$ Section 3(b)(1) of the Securities Act establishes the SEC's exemptive authority for offerings of up to USD 5 million.

62 However, these limitations are inapplicable if the issuer complies with certain state registration requirements. See: Rule 504(b)(1).

63 Pursuant to Rule 506(d) bad actor disqualification, an offering is disqualified from relying on exemptions of Regulation D if the issuer or any other person covered by Rule 506(d) has a relevant criminal conviction, regulatory or court order or other disqualifying event. 
Regulation Articles 1(4)(a) and 1(4)(b)- "private placement" exceptions for qualified and 149 non-qualified investors. In turn, Rule 504 can be confronted with the EU exemption from Article 1(3) — first, because of the value of the threshold (EUR 8 million vs USD 5/10 million), and second, because both exemptions do not preempt the laws of particular states. However, there are many differences. Unlike Rules 506(b) and 506(c), EU exemptions are not preempted from the national laws of the Member States. Second, EU exemptions can be freely advertised and solicited, unlike Rules 506(b) and Rule 504. Most notably, EU law lacks certain investor protection safeguards, such as provisions on resales of restricted securities or bad actor disqualification.

\section{Regulation $\mathrm{A} / \mathrm{A}+$}

The SEC Regulation $\mathrm{A}^{64}$ (which is often referred to as Regulation $\mathrm{A}+$ after the latest reforms) in its current shape was adopted by the SEC in $2015,{ }^{65}$ due to its authority under Section 3(b)(2) of the Securities Act. ${ }^{66}$ Regulation A provides an exemption from registration for public offerings and has two offering tiers: tier 1 , for offerings of up to USD 20 million and tier 2, for offerings of up to USD 50 million- both in a 12-month period. For offerings of up to USD 20 million, companies can choose to proceed under the requirements for Tier 2.

Some basic requirements are applicable to both tiers, such as company eligibility, ${ }^{67}$ bad actor disqualification provisions, ${ }^{68}$ and disclosure obligations, including an offering statement. ${ }^{69}$ Additional requirements that apply solely to Tier 2 offerings include requirements for audited financial statements and filing of ongoing reports. ${ }^{70}$ Furthermore, there are investment limits on the amount of money a non-accredited investor may invest in a Tier 2 offering. The so-called Main Street investors ${ }^{71}$

6417 C.F.R. $\$ 230.251$ et seq. See: SEC Proposed Rule: Facilitating Capital Formation...; SEC 2020 Regulation A. Lookback Study and Offering Limit Review Analysis; Office of the Advocate for Small Business...

65 See: Amendments for Small and Additional Issues Exemptions under the Securities Act (Regulation A), Release No. 33-9741 (March 25, 2015) [80 FR 21806 (Apr. 20, 2015)] ("2015 Regulation A Release"). Regulation A was then revised in 2018; See Amendments to Regulation A, Release No. 33-10591 (Dec. 19, 2018) [84 FR 520 (Jan. 31, 2019)] ("2018 Regulation A Release").

66 Section 3(b)(2) directs the Commission to adopt rules adding a class of securities exempt from the registration requirements of the Securities Act for offerings of up to USD 50 million of securities within a 12-month period.

67 Rule 251(b).

68 Rule 262.

69 The offering statement consists of the contents required by Form 1-A filed with the Commission, including two years of financial statements and any other material information necessary to make the required statements, in light of the circumstances under which they are made, not misleading. See: Rule 252.

70 Such as annual, semi-annual and current reports. See: Rule 257.

71 As opposed to Wall Street investors. 
cannot invest greater than $10 \%$ of their annual income or $10 \%$ of their net worth. ${ }^{72}$ However, unlike under the Tier 1 regime, issuances in Tier 2 offerings enjoy preemption of state registration and qualification.

Regulation A carries important benefits. First of all, securities are available not only to accredited but also to non- accredited investors, which on the one hand gives retail investors investment opportunities, and on the other hand, enables issuers to seek more diversified sources of funding. In addition, issuers utilizing Regulation A+ are permitted to "test the waters" with the potential purchaser and use solicitation materials both before and after filing the special offering statement. ${ }^{73}$ Moreover, securities purchased in offerings under Regulation A are not restricted on resale.

According to research, Regulation A is particularly favored by mature and laterstage companies, which treat its exemption as a stop on the way to regular initial public offering (Regulation A offerings are often referred to as "Mini IPOs"). ${ }^{74}$ The SEC estimates, that from June 2015 till December 2019, issuers under Regulation A reported raising approximately USD 2.4 billion in 382 qualified offerings, the majority of which was raised under Tier 2 (USD 2.2 billion- 90.6 percent). ${ }^{75}$ Despite the fact that the value and volume of Regulation A offerings remain relatively modest (especially compared to registered offerings or Rule 506(b) offerings), ${ }^{76}$ the financing levels after the 2015 amendments become incomparably higher than before. ${ }^{77}$ Moreover, there has been reported a steady increase in the aggregate amount raised annually under Regulation A for the past 3 years $(84 \%$ in 2018 and $42 \%$ in 2019). ${ }^{78}$

Considering the Regulation's young age, as well as its growing popularity, it is hard to deny its success. It is worth- noting that the Regulation A original solutions have no equivalent within the EU, not to mention its generous exemptions (USD 20 and 50 million vs. only EUR 8 million). Moreover, the SEC has recently proposed to increase the maximum offering amount under Tier 2 of Regulation A from

72 For more details see Rule (d)(2)(i)(C).

73 See: Rule 255.

74 Office of the Advocate for Small Business..., p. 12.

75 SEC Proposed Rule: Facilitating Capital Formation..., p. 18.

76 According to the SEC, the financing levels of Regulation A are related to a combination of factors, including: the pool of issuers and investors; the availability of attractive private placement alternatives; the availability to investors of attractive investment alternatives with a more diversified pool of issuers; limited intermediary participation and a lack of traditional underwriting, which limits certification (i.e., signaling of an issuer's growth potential to the market through an underwriter's reputation, which mitigates the information asymmetry about an issuer's potential); potential lack of secondary market liquidity. See: SEC 2020 Regulation A. Lookback Study..., pp. 5-6.

77 Ibidem.

78 SEC 2020 Regulation A. Lookback Study..., p. 11. 
USD 50 million to USD 75 million. ${ }^{79}$ Such a move is believed by the US authorities to further facilitate capital formation by attracting the number of larger issuers, qualified and institutional investors as well as intermediaries to the Regulation A environment. ${ }^{80}$ Since this measure will make Regulation even more competitive from a comparative perspective, it will definitely widen the gap between the US and the EU prospectus exemption framework. Taking this into account, EU lawmakers should consider establishing an exemption threshold that would be in nature similar to Regulation A - with a considerably higher threshold and some form of alleviated disclosure requirements.

\section{Regulation Crowd-funding}

Regulation Crowd-funding ${ }^{81}$ (hereinafter referred to as "Reg. C."), effective from 2016, was adopted by the SEC, due to its authority under Title III of the JOBS Act $^{82}$ which added Securities Act section 4(a)(6). Reg. C. provides an exemption from registration for crowd-funding transactions ${ }^{83}$ under certain conditions. It permits the offer and sale of up to USD 1,070,000 million of securities in a 12-month period $^{84}$ and introduces investment limits for individual investors. ${ }^{85}$ General solicitation and advertising are permitted with certain limitations. ${ }^{86}$ Reg. C. requires all transactions to take place online through an SEC-registered intermediary. ${ }^{87}$

79 SEC Proposed Rule: Facilitating Capital Formation..., p. 116 et seq. See: A Financial System That Creates Economic Opportunities - Capital Markets (October 2017) ("2017 Treasury Report”), https://www.treasury.gov/press-center/press-releases/Documents/A-Financial-SystemCapital-Markets-FINAL-FINAL.pdf (accessed: 1.07.2020).

80 SEC Proposed Rule: Facilitating Capital Formation..., pp. 120-121. See: SEC's Divisions of Corporation Finance and Economic and Risk Analysis: 2020 Regulation A. Lookback Study and Offering Limit Review Analysis ("2020 Regulation A Review") as required by the 2015 Regulation A Release, See: https://www.sec.gov/smallbusiness/exemptofferings/rega/2020Report (accessed: 1.07.2020).

8117 C.F.R. $\$ 227.100$ et seq. SEC Proposed Rule: Facilitating Capital Formation...; see: SEC Report to the Commission: Regulation Crowd-funding (June 18, 2019).

82 Pub. L. No. 112-106, 126 Stat. 306 (2012).

83 "Crowd-funding generally refers to a method of capital raising in which an entity or individual raises funds via the internet from a large number of people typically making small individual contributions", see: SEC Proposed Rule: Facilitating Capital Formation..., p. 19.

84 Rule 100(a)(1) of Regulation Crowd-funding.

85 Pursuant to Rule 100 (a)(2), The aggregate amount of securities sold to any investor across all issuers in reliance on section 4(a)(6) of the Securities Act during the 12-month period shall not exceed: (i) The greater of $\$ 2,200$ or 5 percent of the lesser of the investor's annual income or net worth if either the investor's annual income or net worth is less than $\$ 107,000$; or (ii) 10 percent of the lesser of the investor's annual income or net worth, not to exceed an amount sold of $\$ 107,000$, if both the investor's annual income and net worth are equal to or more than $\$ 107,000$.

86 Pursuant to Rule 203 of Regulation C.

87 A broker-dealer or a funding portal (see: section 4A(a) of the Securities Act (15 U.S.C. 77d$1(\mathrm{a})))$. 
Moreover, it requires that issuers and intermediaries provide certain specified information to investors and the SEC. Purchasers receive restricted securities which cannot be freely resold for a period of 12 months. ${ }^{88}$ Importantly, crowd-funding offerings enjoy preemption of state registration and qualification. Similarly to other exempt offerings, Reg. C. offerings are also subject to "bad actor" disqualification provisions. ${ }^{89}$

The SEC estimates that from May 2016 till Dec. 2019, issuers in Reg. C. raised approximately USD 170 million in 795 completed offerings. ${ }^{90}$ Despite the market's stable growth over time, these numbers should be considered modest ${ }^{91}$ - especially in comparison to main competitors, such as the European Union, United Kingdom or China. For example, in the UK, only in 2017, crowd-funding issuers raised the equivalence of approximately USD 450 million. ${ }^{92}$ There are many reasons for such a transatlantic gap. First, the UK crowd-funding market is significantly older (operating since 2011) and more developed. Second, alongside other EU states, it offers higher offering thresholds regimes than the US (EUR 8 million compared to USD 1 million) and favorable tax treatments of crowd-funding investments. ${ }^{93}$

It is worth noting that in the field of crowd-funding the EU holds an undeniable advantage over the US. Although the EU lacks the coherent legal framework regarding crowd-funding and this matter is still under member states' exclusive discretion, multiple national laws allow crowd-funding offerings of up to EUR 8 million (which is the upper exemption threshold of Prospectus Regulation).

However, to significantly strengthen the US capital formation under Reg. C., the SEC lately proposed ${ }^{94}$ raising the issuer offering limits to USD 5 million and increasing the investment limits for investors..$^{95}$ These changes, if adopted, may fill the gap between the US and the EU crowd-funding and mitigate the European advantage.

88 Unless they are sold to certain persons i.e., the issuer of the securities, an accredited investor. See: Rule 501 of Regulation C.

89 Rule 503 of Regulation C.

90 SEC Proposed Rule: Facilitating Capital Formation..., p. 20.

91 See: Report to the Commission: Regulation Crowd-funding (June 18, 2019), p. 4.

92 See: The 3rd European Alternative Finance Industry Report (2017), Cambridge Center for Alternative Finance, University of Cambridge, https:/www.jbs.cam.ac.uk/faculty-research/centres/alternative-finance/publications/expanding-horizons/\#.XKeZSK_4fcs (accessed: 1.07.2020).

93 SEC Report to the Commission: Regulation Crowd-funding, pp. 15-17.

94 SEC Proposed Rule: Facilitating Capital Formation..., p. 126 et seq.

95 By no longer applying those limits to accredited investors and allowing investors to rely on the greater of their income or net worth in calculating their investment limit. 


\section{Conclusions}

In conclusion, there are several findings that can be drawn from the above analysis.

First, the US exempt offerings framework is more developed, complex and diversified than the EU one. In addition to Regulation D, which more or less mirrors the EU exemption system, the US system contains specific laws governing pre-IPO offerings (Regulation A) and crowd-funding (Regulation Crowd-funding) which find no equivalent in the EU. It can be argued, that this original set of rules is more mature and tailored to the specific needs of certain SMEs, rather than the European "one size fits all approach".

Second, when it comes to offers involving retail investors (non-accredited/ non-qualified investors), the US issuers can raise much larger funds without triggering the obligation to produce a full-blown prospectus. Although, as of 2020, the upper exemption threshold in the EU (EUR 8 million) is higher than under Rule 504 (USD 5 million), the latter will soon likely be increased to USD 10 million. Also, many of the EU Member States (13 out of 27) set up their thresholds at way below EUR 8 million (even EUR 1 million). Moreover, under Regulation A, the issuers in the US can raise up to USD 50 million (USD 75 million due to the latest proposals). In With this regard, the US regulations give issuers much larger funding opportunities at a lower marginal cost, even though they are connected with some additional disclosure requirements.

Third, again from the issuers' perspective, the US exempted offerings rules are generally more stringent and burdensome than European ones. This is, among other things, mostly due to several solutions generally not existent in the EU system, such as the restrictions on advertising and general solicitation (Rule 506(b), Rule 504), restrictions on resales (Regulation D, Regulation Crowd-funding), investment limits for non-accredited investors (Regulation A, Regulation Crowd-funding), additional disclosure rules (Regulation D, Regulation A, Regulation Crowd-funding) and ongoing reporting requirements after the offer (Regulation A, Regulation Crowd-funding). However, this is partly mitigated by two factors. First, unlike most of the US exemptions, the EU exemptions do not preempt the requirements of the particular Member States, which in many cases are almost as costly and burdensome. Secondly, with the EU exemptions comes a great deal of uncertainty when it comes not only to national rules and competent authorities procedures but also differing civil liability regimes. The above impacts the small issuers' decision- making process as to conducting the offer. Undoubtedly, the presence of various exemption thresholds and different requirements in each jurisdiction increase transaction costs for small and medium enterprises and may lead to severe fragmentation of EU capital markets. 
Fourth, from the perspective of market oversight and investor protection, the EU prospectus law provides for much laxer rules than its US counterpart. ${ }^{96}$ The Prospectus Regulation completely lacks important investor protection safeguards, such as proportional (yet carefully scaled) disclosure, investment limits for non-qualified investors, provisions on resales of restricted securities, disqualification rules for bad actors, or gatekeeper regulations. ${ }^{97}$ Even a limited disclosure regime would probably eliminate many fraudulent issuances and increase investor protection. This would translate into increased public confidence in smaller issuers, who naturally are more prone to investment risk. In turn, the investment limits can prevent retail investors from losing all their money after investing in a risky offering, while bad actors' disqualification can eliminate fraudulent persons, who are willing to take advantage of the exemptions under EU law. ${ }^{98}$ When it comes to investor protection in exempted offerings, it seems that the US prospectus law has it right.

In conclusion, the comparative analysis indicates, that the US solutions hold a certain advantage over their European counterparts. First, they provide issuers with much larger funding opportunities at a lower marginal cost. Second, they provide more investment opportunities for retail investors. Last but not least, they provide important investor protection safeguards, which are absent under European law.

\section{References}

\section{Literature}

Casale A., Bianchi M., Spatola P., “The New Prospectus Regulation: A Missed Opportunity?”, Oxford Business Law Blog, 2017, https://www.law.ox.ac.uk/business-law-blog/blog/2017/03/ new-prospectus-regulation-missed-opportunity (accessed: 1.07.2020).

Chyla Ł., "Is a 2.5 million EUR prospectus exemption threshold enough?", Przeglad Prawno-Ekonomiczny 47, 2019.

Fox M.B., "Initial Public Offerings in the CMU:A US Perspective", [in:] Capital Market Union in Europe, ed. D. Busch, Oxford 2018.

Härkönen E., "Crowdfunding and the Small Offering Exemption in European and US Prospectus Regulation: Striking a Balance Between Investor Protection and Access to Capital?", European Company and Financial Law Review 14, 2017, no. 1.

Howell E., "An Analysis of the Prospectus Regime: The EU Reforms and the 'Brexit' Factor", European Company and Financial Law Review 15, 2018, no. 1.

Langevoort D.C., "Primary Markets and the Securities Laws: Capital-Raising and Secondary Trading”, New Special Study 2018.

Loss L., Seligman J., Paredes T., Fundamentals of Securities Regulation, Warszawa 2018.

Moloney N., “Capital Markets Union: 'ever closer union' for the EU financial system”, European Law Review 41, 2016, no. 3.

96 E. Härkönen, op. cit., p. 140.

97 Such as under US Regulation Crowd-funding.

98 E. Härkönen, op. cit., p. 146. 
Warren M.G., "Reflections on Dual Regulation of Securities: A Case Against Preemption (May 1, 1984)", Boston College Law Review 25, 1984, no. 3.

\section{Regulations and reports}

The 3rd European Alternative Finance Industry Report (2017), Cambridge Center for Alternative Finance, University of Cambridge.

Amendments for Small and Additional Issues Exemptions under the Securities Act (Regulation A), Release No. 33-9741 (March 25, 2015) [80 FR 21806 (Apr. 20, 2015)].

Capital Markets Union- Communication of the Commission of 30 September 2015, entitled Action Plan on Building a Capital Markets Union.

Directive 2003/71/EC of the European Parliament and of the Council of 4 November 2003 on the prospectus to be published when securities are offered to the public or admitted to trading and amending Directive 2001/34/EC.

Divisions of Corporation Finance and Economic and Risk Analysis: 2020 Regulation A Lookback Study and Offering Limit Review Analysis.

ESMA Document no 31-62-1193 (issued 2.03.2020).

The European Commission Staff Working Document Impact Assessment accompanying the document Proposal for a Regulation of the European Parliament and of the Council on the prospectus to be published when securities are offered to the public or admitted to trading, Brussels, 30.11.2015.

A Financial System That Creates Economic Opportunities - Capital Markets (October 2017).

Regulation (EU) 2017/1129 of the European Parliament and of the Council of 14 June 2017 on the prospectus to be published when securities are offered to the public or admitted to trading on a regulated market, and repealing Directive 2003/71/EC.

Securities Act of 1933 (15 U.S.C. $\S 77$ a et seq.).

Securities Exchange Act of 1934 (15 U.S.C. § 78a et seq.).

SEC 2020 Regulation A. Lookback Study and Offering Limit Review Analysis.

SEC Office of the Advocate for Small Business Capital Formation Annual Report for Fiscal Year 2019.

SEC Proposal: Facilitating Capital Formation and Expanding Investment Opportunities by Improving Access to Capital in Private Markets, SEC Release Nos. 33-10763; 34-88321; File No. S705-20.

SEC Proposed Rule: Facilitating Capital Formation and Expanding Investment Opportunities by Improving Access to Capital in Private Markets, Release Nos. 33-10763 (March 31, 2020).

SEC Concept Release on Harmonization of Securities Offering Exemptions, Release No. 33-10649 (June 18, 2019) [84 FR 30460 (June 26, 2019)], at Section II.

SEC Regulation A (17 C.F.R. \$230.251 et seq.).

SEC Regulation D (17 C.F.R. \$230.501 et seq.).

SEC Regulation Crowd-funding (17 C.F.R. \$227.100 et seq.).

SEC Report to the Commission: Regulation Crowd-funding (June 18, 2019). 